\title{
腸内細菌叢と免疫の関わり
}

\author{
種 本＼cjkstart俊，筋 野 智 久，金井隆 典
}

\section{Intestinal immune response is regulated by gut microbe}

\author{
Tanemoto Shun, Sujino Tomohisa and Kanai TAKANORI \\ Division of Gastroenterology and Hepatology, Department of Internal Medicine, Keio University School of Medicine
}

(Accepted October 6, 2017)

summary

Human Intestine has a diverse population of bacteria which induces pathogens to disrupt not only the intestinal homeostasis but whole body immune systems. Dysbiosis, the abnormal proliferation and reduction of the microbiota, breaks down the homeostasis of the immunity and metabolisms in the host. The evolution of the microbiota analysis technology contributed to reveal the molecular biological complex interaction between the microbiota and its host systemically as well as locally. Because several diseases are caused by the dysbiosis, fecal transplantation would be the new therapeutic target for them. It has been investigated in some intestinal diseases such as CD infection, or inflammatory bowel disease. Here, we review these symbiotic interactions and the current state for the clinical application.

Key words_— microbiota; immunity; inflammatory bowel disease; fecal microbiota transplantation

\section{抄 録}

ヒトには 1000 種，100 兆個を超える腸内細菌が存在する。これらが構成する腸内細菌叢は免疫や代謝を介して 宿主であるヒトと複雑な相互作用を形成し恒常性を維持している，腸内細菌叢の構成菌種の変容や異常増殖，減少 はdysbiosis と呼ばれ，ヒトの腸管のみならず，全身の免疫系，代謝機構に異常を引き起こす．脂肪肝炎やメタボリッ クシンドローム，関節リウマチ，自閉症，多発性硬化症などさまざまな疾患にdysbiosis が寄与している可能性が 示唆されている。近年の腸内細菌解析技術の発展により，ヒトの腸内細菌叢を構成する菌種の同定のみならず，代 謝やタンパク質発現を介した複雑な相互関係が明らかになってきている。また，腸管上皮細胞や免疫細胞と腸内細 菌との相互作用の実際が分子レベル，遺伝子発現レベルで明らかになってきており，それぞれの疾患の病態解明や 新しい治療対象として実用化が期待される。炎症性腸疾患においてはCrostridium butyricum などの酪酸産生菌が炎 症抑制作用を持ち，注目を集めている。また腸内細菌叢を対象としたFMT（Fecal microbiota transplantation）も実 用化に向けて検討が進められている段階である.

\section{はじめに}

ヒトの腸管内には 1000 種, 100 兆個を超える腸 内細菌が存在し，宿主以上に独自の遺伝子を発現し ている ${ }^{1)}$. 粪便 $1 \mathrm{~g}$ あたりには $10^{11} \sim 10^{12}$ 個の細菌が 含まれるといわれている。腸管にはこれらの細菌が 形成する腸内細菌叢や病原体に対する防御機構が存 在するが，腸管免疫の構築には腸内細菌叢と宿主の 免疫機能との複雑な相互作用が大きく関与すること が知られている。また，食物繊維の代謝に代表され るように，宿主は代謝，栄養の観点からも腸内細菌

慶應義塾大学医学部内科学（消化器）
叢から様々な恩恵を受け, 共生関係を築いている.

通常, 腸内細菌叢と宿主の関係は復元力が強く, 抗菌薬投与などの結果一時的に乱れたとしてもやが てもとに戻り，恒常性を維持している。この腸内細 菌叢の構成菌種，バランスが変容し，量的・質的 異常を来した状態をdysbiosis と呼ぶ. dysbiosisに よって腸管免疫の恒常性は破綻し, 異常な免疫反 応，代謝機構の乱れが生じる。近年，炎症性腸疾患 (Inflammatory bowel disease: IBD) や過敏性腸症候群 などの消化管疾患のみならず，非アルコール性脂肪 肝炎, 肥満, 糖尿病, 多発性硬化症, パーキンソン 病，関節リウマチ，さらに自閉症など，様々な分野 において dysbiosis との関連が報告され, 腸内細菌 


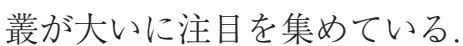

IBD に関しては, dysbiosisによって腸管免疫の恒 常性が崩れ，慢性的な炎症が惹起されることが病態 仮説として考えられている。腸内細菌叢と腸管免疫 との相互作用，IBD との関連性について述べる。

\section{腸内細菌叢の解析技術}

近年腸内細菌叢に関する研究が飛躍的に進歩して いるが, その背景に解析方法の変遷がある. 腸内細 菌叢を個々に分離培養する従来の方法では, 最新の 嫌気培養技術を駆使しても約 $80 \%$ は培養困難か細 菌数が極端に少ないという問題があり，解析可能な 細菌は限定されていた。

近年用いられている方法が 16SrRNAを標的とし た分子生物学的方法である。16SrRNA はウイルス 以外の全生物に存在し, リボソームを構成する構造 RNAの一つであり, 高度に保存された共通の領域 と比較的変異しやすい多様化領域を持つ。この保存 領域にプライマーを設計して増幅後に，9 か所（v1 〜 v9）からなる多様化領域を比較することで, 構 成菌の同定が可能となった。さらに現在では, 細菌 丵全体の機能的特徵を類推する解析方法として, メ 夕ゲノム解析も一般化してきている. 次世代シーク エンサーを用いたメタゲノム解析や，代謝物（メ夕 ボローム）解析，網羅的な蛋白質発現（メタプロテ オーム）解析などを組み合わせ, 腸内細菌叢の構成 菌種のみならず, 炭水化物やアミノ酸代謝などの機 能を含めた様々な角度から宿主と腸内細菌の関係性 が解析可能となっている.

\section{ヒト腸内細菌叢の構成}

前述の 16SrRNA を用いた解析により, 腸内細菌 叢の構成菌種が明らかとなっている。健常人の腸内 に生息する腸内細菌叢はFirmicutes 門, Bacteroidetes 門，Proteobacteria 門および Actinobacteria 門によっ てその $90 \%$ 以上が構成されている2). 中でも Firmicutes 門が最も優勢で約 $60 \%$ を占めており, Bacteroidetes 門が約 20\%でこれに次ぐ。dysbiosis の状態 では，これらの構成菌種のバランスや多様性が失わ れ，偏った組成となっている。最近の研究では, IBD やメタボリックシンドロームなどさまざまな病 態において dysbiosis が発症，増悪に関連すると考 えられている(表1). IBDにおいてはFirmicutes 門とBacteroidetes 門の細菌が減少し, 一方 Proteobacteria 門とActinobacteria 門の細菌が増加している
表 1 腸内細菌叢の変化との関連が指摘されている疾患

\begin{tabular}{ll}
\hline \hline \multicolumn{1}{c}{ 消化管疾患 } & \multicolumn{1}{c}{ 消化管以外の疾患 } \\
\hline Clostridium Difficile 感染症 & 肥満 \\
炎症性腸疾患 (IBS) & 糖尿病・耐糖能異常 \\
過敏性腸症候群 & 非アルコール性脂肪肝炎 \\
大腸癌 & 喘息 \\
& アトピー性皮膚炎 \\
& 自己免疫性疾患 \\
& 慢性疲労症候群 \\
& 多発性硬化症 \\
& 自閉症 \\
\hline
\end{tabular}

Gastrointest Endosc 78: 240-249, 2013 を参考に作成.

ことが分かっている ${ }^{3)}$. Firmicutes 門の主要構成菌 種である Clostridium 属 cluster IV と XIVa の細菌は, 酪酸産生において中心的な役割を果たし，制御性 T 細胞（regulatory T cell: Treg 細胞）の分化誘導を促 すことで腸管免疫の恒常性の維持に大きく貢献して いることがマウスを用いた研究で明らかになってい $ろ^{4)}$.

\section{腸管粘膜における防御機構}

dysbiosis と IBD や様々な疾患との関連の背景に は, 腸内細菌と腸管免疫の複雑な相互作用が存在す る。腸管には膨大な腸内細菌と食餌抗原などの外的 抗原に対する生体防御機構が備わっている。これ は，腸粘膜を被覆する粘液層や腸管上皮細胞表面に 存在する糖夕ンパクの糖鎖などの物理的な防御機 構, ディフェンシンやラクトフェリン, リゾチーム などの抗菌分子からなる化学的な防御機構, そし て，末梢の 60〜 70\%が集中しているとされる免疫 細胞が形成する複雑な免疫応答によって形成されて いる（図1）。

\section{上皮バリア}

大腸の粘膜では杯細胞が分泌する分泌型ムチン であるMuc2 を主成分とする粘液層が形成されてい る.Muc2 は互いに密に結合した構造をとり,さら に $\mathrm{O}$ 型糖鎖が粘性を生み出す。また，グリコシル ホスファチジルイノシトールアンカー型タンパクの Lypd8 が腸管上皮から大腸管腔に遊離され，有鞭毛 細菌の鞭毛部分に結合することで腸内細菌の侵入を 抑制している5)。これらのはたらきによって粘液層 の腸管上皮側は無菌状態に保たれ，腸内細菌と腸管 上皮を分け隔てている。

一方杯細胞に乏しい小腸では粘液層は薄いが 


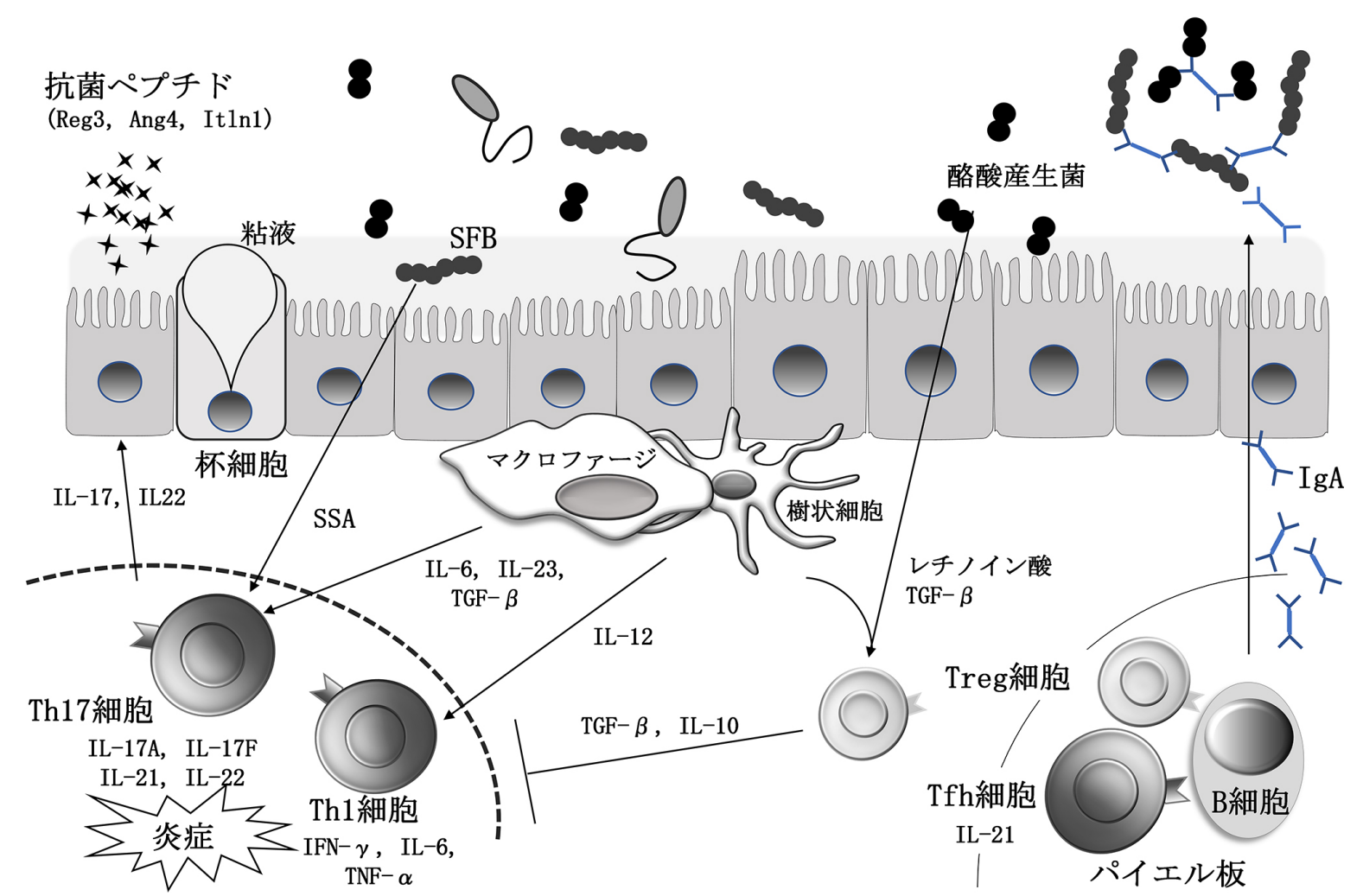

図 1 腸内細菌と免疫細胞の相互作用

腸内細菌が産生する酪酸や，樹状細胞が分泌するレチノイン酸，TGF- $\beta$ などが Foxp3 陽性 Treg 細胞を誘導し，炎症抑制的に はたらく．Th17 細胞などが産生する IL-17 や IL22 は腸管上皮細胞，胚細胞に作用して抗菌ぺプチドや粘液の分泌を促し，腸管 バリア機能に関与する。Foxp3 陽性 Treg 細胞はパイエル板において Tfh 細胞へと分化し B 細胞のクラススイッチと IgA 産生に 関与する

dysbiosis の状態ではこのような防御機構が機能せず，Treg 細胞の減少や，腸管上皮への腸内細菌の侵入がみられる．Toll 様受 容体を介して刺激を受けてマクロファージや樹状細胞などの自然免疫系が不活化され，IL-6 や Il-12，SFB からの SSAを介した シグナルは Th17 細胞や Th1 細胞を誘導し，炎症を惹起する。

Paneth 細胞などから産生されるディフェンシンや Reg3 ファミリー分子などといった抗菌ペプチドが 腸内細菌の接着や侵入を妨げる。塩基性アミノ酸を 多く含むディフェンシンは正に荷電し, 負に荷電し た腸内細菌細胞膜へ接着する。その後ディフェンシ ンの疎水性領域が細胞膜の透過性を㐫進させること で抗菌作用を示す ${ }^{6}$.

これらの粘液や抗菌ペプチドの分泌は, Th17 細 胞や ROR $\gamma \mathrm{t}$ 陽性細胞などが分泌する IL-17 や IL-22 などのサイトカインによって大きく制御されてい る。一方で腸内細菌の細胞成分や代謝産物を認識し た TLR 刺激から NLRP6（NACHT-LRR-PYD-domaincontaining protein）インフラマソームの経路を介し た IL-18 産生を経て，Reg3などの抗菌ペプチドや 粘液の分泌を制御する経路も存在する。NLRP6を 欠損したマウスでは，腸内細菌の構成や機能の変容 （dysbiosis）や，腸管感染症がみられる。このよう に腸管上皮細胞では粘液や抗菌ペプチドなどが腸内 細菌に対する生体防御を担う一方で，これらの分泌
と腸内細菌叢の間には腸管の恒常性を保つ上で重要 な相互作用が存在している,

\section{IgA と腸管免疫}

腸管の免疫細胞は，パイエル板や孤立リンパ小節 などの腸管関連リンパ組織（Gut associated lymphoid tissue: GALT）や，腸管粘膜固有層，および腸管上 皮などに分布し，それぞれ存在する種類や機能が 異なっている。 IgA 産生性 B 細胞や, Treg 細胞, Th17 細胞などが腸管免疫を担当する免疫細胞とし て代表的である。

パイエル板は免疫誘導組織であり, 抗原に暴露さ れていないナイーブ T 細胞や B 細胞が多く存在す る。組織学的にはリンパ濾胞と濾胞間領域などの構 造を有し，リンパ濾胞では胚中心において B 細胞 が IgM 産生性のものから IgA 産生性のものへクラ ススイッチされる。これは $\operatorname{IgA}$ 産生性 B 細胞の生 存㧍よび増殖に必要とされるケモカイン, サイトカ イン，およびレチノイン酸などが豊富に存在する微 
小環境に依存している ${ }^{9,10)}$. IgA 産生性 B 細胞はク ラススイッチの後, パイエル板を離れ大循環を経て 再び粘膜固有層へと戻る.

また，パイエル板では濾胞性 $\mathrm{T}$ 細胞 ( $\mathrm{T}$ follicular helper cell: Tfh 細胞）が重要な役割を果たす。Tfh 細胞はパイエル板において, 樹状細胞などが産生す る IL-6 などの働きにより Foxp3 陽性 T 細胞から分 化することが知られている。Tfh 細胞は Chemokine Receptor 5 を発現しリガンドである Chemokine ligand 13 が豊富に存在するリンパ濾胞内へ遊走し, IL-21 を産生し B 細胞の増殖と分化を制御する。 Bcl6を 欠損したマウスでは Tfh 細胞が減少し, パイエル板 の低形成が認められることが分かっている ${ }^{11,12)}$.

分泌された $\operatorname{IgA}$ は二量体として上皮細胞の基底 膜に発現しているポリ免疫グロブリン受容体に結合 し, 小胞体輸送により基底膜側から管腔側へと輸送 される，腸管内で IgA は病原菌の腸管粘膜からの 侵入の阻止，毒素やウィルスの中和などを担う．

B 細胞の抗体クラススイッチや分化に関わる AID を欠損したマウスでは腸内細菌の異常増殖や腸炎の 発症が確認され, B 細胞の過形成によるパイエル板 の腫大がみられる。そして抗菌薬を投与し腸内細菌 を減少させると，B 細胞の過形成が収束することが 報告されている。また逆に，無菌マウスにおいては IgA 産生細胞の数が顕著に減少しており, 腸内細菌 の存在がその分化に必要であることが明らかになっ ている ${ }^{13)}$. 近年の研究では特に多くの細菌への結合 能力を有する W27IgA 抗体が同定され，腸炎モデル マウスに W27IgA 抗体を経口投与すると腸炎が抑制 されると報告されている年)。さらにW27IgA 抗体は 細菌の増殖にかかわる代謝酵素であるセリンヒドロ キシメチルトランスフェラーゼの一部のアミノ酸配 列を認識して, 大腸菌には強く結合し, 乳酸菌やビ フィズス菌のような腸炎抑制的にはたらく細菌には ほぼ結合しないという特徵を持っていた。

\section{腸内細菌と腸管炎症}

IBD の発症原因は未だ不明であるが, 遺伝学的素 因や環境因子などの多因子疾患であると考えられて いる. IBD の疾患感受性遺伝子としては, NOD2や ATG16L1, IRGM, TLR4, LRRK2, NCF4, FUT な どの細菌認識・制御, 粘膜防御に関連する遺伝子 が多く報告されている ${ }^{15)}$ ，腸内細菌叢の異常である dysbiosis も腸管炎症の原因の一つと言われており, 近年の腸内細菌解析技術の発展や，無菌マウスモデ
ルの汎用化に伴い, 腸管炎症に関与する菌種や, 代 謝・免疫応答の機序などについて，急速に解析が進 んでいる。ここでは dysbiosis と腸管炎症の関係性 について, 腸内細菌と免疫細胞の相互作用に注目し て述べていく.

\section{Th17 細胞と腸内細菌叢}

例えば IL-10ノックアウトマウスや CD45Rbhi 移 入モデルマウスなどの遺伝子改変腸炎モデルマウス は，無菌環境下においては腸炎を発症しない。同じ く自然腸炎モデルマウスである T-bet と RAG2 の二 重ノックアウトマウスを野生型のマウスと同じケー ジで飼育すると，野生型のマウスも腸炎を発症する。 これは腸炎モデルマウスの腸内細菌が糞便を介して 野生型マウスの腸炎を誘導するためと考えられ，腸 内細菌の異常が腸炎の原因となることを支持してい る.

dysbiosis が腸炎を惹起する機序としては，腸管炎 症の原因として知られている Th17 細胞の誘導や, 腸管粘膜の粘液層の分解を介して炎症が引き起こさ れることなどが考えられている。Th17 細胞は， IL17A や IL-17F，および IL-22 などのサイトカインを 産生し, 好中球の集積や炎症を惹起する ${ }^{16)}$. さら に，上皮細胞による抗菌ペプチドの産生を促進し上 皮細胞の tight junction を密着させ，またGALT 内で の IgA 産生も促進する作用を持つ ${ }^{17)}$ 。マウスにおい ては，セグメント細菌（Segmented filamentous bacteria: SFB）が Th17 細胞を分化誘導する腸内細菌の 一種として同定されている.SFB は小腸粘膜に接着 し, 血清アミロイド A や活性酸素種の産生を促進 させるなどの機序により Th17 細胞の誘導に重要な 役割を果たしている ${ }^{18)}$.SFB はマウスやラットをは じめ多くの動物種で腸内細菌共生細菌としての存在 が報告されているが，これまでのヒトの腸内細菌叢 の解析では SFB はヒトの腸内には存在しないと考 えられる。

ヒトでは，Atarashiらは無菌マウスに健常人およ びUC 患者の糞便を定着させることでマウスの大腸 粘膜にTh17 が誘導されることを報告した。 また, これらのマウスの腸内細菌を解析し, Th17 の誘導 に相関する 20 種の腸内細菌を無菌マウスに定着さ せることでやはり大腸粘膜において Th17 の誘導が 認められた ${ }^{19)}$ 。このことから，ヒトの腸管にも， SFB と同様に Th17 を誘導し腸管炎症を引き起こす 腸内細菌が存在することが示唆されている. 
このうち同定されている菌種は少ないが，例え ば, Adherent-invasive Escherichia coli (AIEC) は腸 管上皮細胞への接着性を持つ特殊な大腸菌であり, IBD 患者の半数以上において増加が認められ，原因 菌として考えられるものの一つである。この大腸菌 は線毛付着因子である Fim1 の変異やリポ多糖産生 能の増強から腸管上皮細胞への強い接着能を持ち, 腸管上皮へ侵入し炎症性マクロファージを増加さ せることが知られている20,21).ささらに，IL-10ノッ クアウトマウスの慢性腸炎モデルに AIEC を移入す ると, Th17 や Th1 の増加を伴う腸炎の悪化を認め る。また，近年ヒトの常在菌である Bifidobacterium adolescentis も，マウスにおいてTh17 誘導するこ とが確認されている22).

\section{Treg 細胞と腸内細菌丵}

Th17 を誘導して腸炎を惹起する腸内細菌が存在 する一方で，腸炎抑制的にはたらく腸内細菌も報告 されている。 IBD 患者の腸内細菌叢を解析すると， 先述の通り腸内細菌叢の構成菌の多様性低下を認 め, Firmicutes 門の酪酸高生産菌であるCostridium 属 cluster IV と XIVaの減少が認められる。これら の変化は特にクローン病（Crohn's disease: CD）で 認められることが多い。中でも CD 患者に打ける F.prausnitzii の減少が多数報告されており，小腸型 CD の術後再発率が F.prausnitzii の減少と相関する との報告もある ${ }^{23)}$.

F.prausnitzii はヒト末梢血単核球からの IL-10 産生 を誘導し，またその培養上清は腸上皮細胞の NF-kB の活性化を抑制することで，抗炎症作用を示す ${ }^{24)}$. 健常人に抢いて F.prausnitzii と便中酪酸濃度との相 関関係が報告されており，F.prausnitzii は酪酸を介 して腸管炎症に対して制御的に働いていると考えら れる。

酪酸はヒストン脱アセチル化酵素阻害活性を有し， Foxp3 遺伝子のプロモーターおよびエンハンサー部 分のアセチル化を促進することで，大腸粘膜固有層 におけるナイーブ T 細胞の Treg 細胞への分化を制 御している ${ }^{25)}$ 。 また，大腸マクロファージは大腸粘 膜固有層に最も多く存在する免疫細胞であるが，他 の組織のマクロファージと異なり TLR 刺激に低感 受性であり，炎症に抑制的に働くことが知られてい る。これは，やはり酪酸のヒストン脱アセチル化酵 素阻害活性により，IL-6 や IL-12 などのサイトカイ ン産生が抑制されることによる。
また, Costridium butyricum はマウスの腸管粘膜 固有層において, Treg 細胞分化に極めて重要な因 子である TGF- $\beta$ の発現を上昇させることが明らか となっている。腸炎モデルマウスにC. butyricum を 経口投与すると, 粘膜固有層で Treg 細胞が増加し ており，IL-6 や TNF $\alpha ， I L-12$ などの炎症性サイト カインの減少がみられる一方で, TGF- $\beta$ や IL-10 と いった抗炎症性サイトカインの発現には上昇がみら れた。ささらに，TGF- $\beta$ は樹状細胞がTLR2を介して C.butyricum のペプチドグリカンを認識することで 分泌されることが明らかとなった ${ }^{26)}$.

このように，腸内細菌と免疫細胞との間には複雑 な相互作用が存在し, 腸内細菌叢の構成菌のバラン スによって腸管免疫の恒常性は維持されている. IBD 患者にみられる dysbiosis はこの恒常性を破綻 させ，過剩な免疫応答を引き起こすことで慢性炎症 の原因となっていると考元られ，腸内細菌を対象と した IBD 治療の可能性が示唆される.

\section{腸内細菌をターゲットとした治療戦略}

現在行われている IBD 治療は 5-アミノ酸サリチ ル酸製剂を基本として，ステロイドや calcineurin 阻 害薬といった免疫抑制椷, アザチオプリンに代表さ れる免疫調節薬などに加え, 近年は抗 TNF- $\alpha$ 抗体 製剤，抗 IL-12/23p40 抗体製剤などが登場した。こ のように免疫を対象とした治療方法が中心となって いるのが現状である。抗菌薬やプロバイオティクス などによる治療介入が UC 術後の回腸囊炎や, 膿瘍. 㾇孔を有する CD には一部有効であるという報告が あり，実臨床において腸内細菌を想定した治療も一 部では行われているが限定的である。

近年の腸内細菌叢の解析が進むにつれて, dysbiosis と IBDの関連が明らかになりつつあり，腸内細 菌を対象とした新規治療の可能性が期待されている （表 2 ）。腸内細菌を対象とした IBD 治療としては, プロバイオティクスや糞便微生物移植 (Fecal microbiota transplantation: FMT) などの有用性が検討され てきた，プロバイオティクスについては，軽症の潰 瘍性大腸炎（Ulcerative colitis: UC）患者を対象とし て, Escherichia coli Nissle 1917 株を含む 8 種類の細 菌を混合したVSL\#3 という合剤が，既存の寛解導 入療法に対する上乗せ効果を示した RCT が報告さ れている27)。また，C.butyricum が腸炎モデルマウ スの大腸粘膜固有層において Treg 細胞分化を誘導 し腸炎抑制的にはたらくことを先に述べたが，この 
表 2 炎症性腸疾患患者にみられる腸内細菌叢の変化

\begin{tabular}{|c|c|}
\hline Expanded (potentially inflammatory) & Contracted (potentially protective) \\
\hline Firmicutes 門 & Firmicutes 門 \\
\hline Ruminococcus gnavus $^{\mathrm{a}}$ & Clostridium Group IV, Group XIVa ${ }^{* \mathrm{~b}}$ \\
\hline Veillonellaceae & Roseburia species $^{*}$ \\
\hline 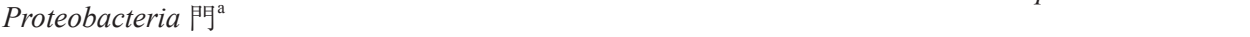 & Faecalibacterium prausnitzzi ${ }^{* \mathrm{~b}}$ \\
\hline Escherichia coli & Proteobacteria 門 \\
\hline adherent/invasive $(A I E C)^{\mathrm{a}}$ & Sutterella species \\
\hline \multicolumn{2}{|l|}{ Pasteurellaceae } \\
\hline Fusobacteria 門 & Bacteroides $^{* \mathrm{~b}}$ \\
\hline \multicolumn{2}{|l|}{ Fusobacterium species ${ }^{*}$} \\
\hline Fungi & Bifidobacterium $s p^{*}$ \\
\hline \multicolumn{2}{|l|}{ Clavispora lusitaniae } \\
\hline Kluyveromyces marxianus & Fungi \\
\hline Candida albicans, Cansida tropicalis & Saccharomyces cerevisiae \\
\hline \multicolumn{2}{|l|}{ Cyberlindnera jadinii } \\
\hline \multicolumn{2}{|l|}{ Virus } \\
\hline Caudovirales & \\
\hline
\end{tabular}

IBD 患者では腸内細菌の減少，構成菌種の多様性低下が指摘されている。炎症惹起性の腸内細菌（Proteobacteria，Fusobacterium，Ruminococcus）の増加㧍よび腸炎抑制性の腸内細菌（Clostridiuum, Bifidobacterium, Faecalibacterium prausnitzii）の減少が報告されている。腸内細 菌が分泌する酪酸は腸炎抑制性にはたらくが，Fusobacterium variumが分泌する高濃度酪酸は細胞傷害性にはたらくと考えられている。 a マウス実験的腸炎を発症させる報告があるもの b マウス実験的腸炎を改善・抑制する報告があるもの * 酪酸産生菌 Gastroenterology 152: 327-339, 2017 を参考に作成.

報告に使用された C.butyricum MIYARI 588 株はヒト に経口投与されるプロバイオティクス製剤に含まれ る菌の一つである。

FMT は Clostridium difficile 感染症（Clostridium diffcile infection: CDI) に対する有効性が 1980 年代 から報告されている。 CDI は抗菌薬の投与を契機と したC.difficileの異常増殖を背景とする感染症であ る。治療には vancomycin や metronidazoleなどの抗 菌薬が用いられるが，15２0\%に再発が認められ， その $45 \%$ にさらに再発がみられるという報告が ある。このような難治再発例では腸内細菌叢の構成 菌の多様性が失われており, 耐性菌の出現や dysbiosis への関与が懸念されることから, 抗菌薬以外の 治療法が求められていた。 2013 年に再発性の CDI に対する FMT の有效性を検討する $\mathrm{RCT}^{28)}$ において FMT が既存の抗菌薬治療に対する優越性を示し注 目を集める結果となった。 FMT 施行群で無再発率 $94 \%$, 既存の抗菌薬治療単独群では無再発率 31\% と FMT の高い奏効率が認められた。その後 dysbiosis との関連が注目されている IBD や過敏性腸症候 群, メタボリックシンドロームなどへの応用も検討 されるようになった。

IBD に対するFMT については本邦を含めて複数 の検討がされており，有効性を示す報告も散見さ
れる。著者らの施設では 10 名の中等症から重症の UC 患者に対して大腸内視鏡下で単回の FMT を行 いその有効性を検討したが，1名に臨床的改善を認 めるのみであり有効性は示されなかった ${ }^{29)}$ 。また, 他に本邦では 41 名の UC 患者に対する単回の FMT を施行した報告があるが，寛解導入に至った患者は おらず，28.6\%（11/41）に臨床的改善を認めたとい う結果で, 有効性は十分ではないという結論であっ た。

海外では2015年に Moayyedi らとRossen らが RCT の結果を報告した（表 3 ）。 Moayyedi らの報 告 ${ }^{30)}$ では 75 名の UC 患者に対して週 1 回粪便もし くはプラセボを 6 週間注腸投与し， 7 週時点での寛 解導入率は FMT 施行群で $24 \%$, プラセボ投与群で は 5\%と有意差をもって FMTによる寛解導入効果 が示された。この RCTでは特定のドナーの粪便を 投与された患者で寛解導入率が高かったことや，抗 $\mathrm{TNF} \alpha$ 抗体製剤の使用などが交絡因子として影響し ている可能性がある。一方 Rossen $5^{31)}$ は抗 $\mathrm{TNF} \alpha$ 抗体製剂を使用していない 50 名の UC 患者に対し てチューブを経鼻的に挿入し，十二指腸にドナーの 糞便もしくはプラセボとして患者自身の糞便を投与 した。投与は 3 週間隔で 2 回行われた。この RCT では奏効率に有意差は認められなかった。さらに 
表 3 潰瘍性大腸炎に対する FMT の報告

\begin{tabular}{|c|c|c|c|c|c|c|}
\hline 報告者 & ドナー便 & プラセボ & 投与経路 & 投与回数 & 主要評価項目 & 結果 \\
\hline $\begin{array}{l}\text { Moayyedi } \\
(2015)\end{array}$ & 健常人 & 水 & 注腸 & 6 回（週 1 回） & $\begin{array}{l}7 \text { 週時点での臨床的寛 } \\
\text { 解導入率 }\end{array}$ & $\begin{array}{l}\text { 有意差あり } \\
(24 \% \text { vs 5\%) }\end{array}$ \\
\hline $\begin{array}{l}\text { Rossen } \\
(2015)\end{array}$ & 親族，パートナー & 患者便 & $\begin{array}{c}\text { 経鼻チューブ } \\
\text { (十二指腸 })\end{array}$ & 2 回 (0 週, 3 週) & $\begin{array}{l}12 \text { 週時点での臨床的寛 } \\
\text { 解かつ内視鏡的改善 }\end{array}$ & $\begin{array}{c}\text { 有意差なし } \\
(30 \% \text { vs } 25 \%)\end{array}$ \\
\hline $\begin{array}{l}\text { Paramsothy } \\
\text { (2017) }\end{array}$ & $\begin{array}{c}\text { 複数のドナー便の } \\
\text { 混合 }\end{array}$ & 生理食塩水 & $\begin{array}{c}\text { 注腸 } \\
\text { (初回大腸内視鏡) }\end{array}$ & $\begin{array}{l}\text { 初回投与後, } \\
40 \text { 回（週 } 5 \text { 回） }\end{array}$ & $\begin{array}{l}8 \text { 週時点でのステロイ } \\
\text { ド離脱と, 内視鏡的寛 } \\
\text { 解もしくは改善 }\end{array}$ & $\begin{array}{l}\text { 有意差あり } \\
(27 \% \text { vs 8\%) }\end{array}$ \\
\hline
\end{tabular}

2017 年, Paramsothy らは 85 名のステロイド治療を 受けている活動性 UC 患者に対して，初回は大腸内 視鏡下でドナーの糞便もしくはプラセボを投与し， その後は注腸投与にて週 5 回，8週間続けて粪便， プラセボを投与する RCT を報告した ${ }^{32)}$ ，その結果， FMT 施行群では $27 \%$ ，プラセボ群で $8 \%$ の患者が ステロイド治療を離脱し寛解を得ており，有意差を もって FMT 群での奏効率が高かった。このように UC 患者に対する FMT は有効である可能性も示さ れているが，著者らの検討を含め単回の FMT では 効果は限定的であると考えられる。ドナーの選択や 投与回数，投与経路などについてのプロトコールを 含めて今後さらなる検討が望まれる。CDに関して は RCT の報告はないが，30 症例に対する検討 ${ }^{33)}$ で 76.7\%（23/30）が臨床的寛解を達成し，栄養状態や 炎症所見に改善を認めたとの報告があり，さらなる 検討が望まれる。

近年 CDI に対して糞便移植を改良し，糞便中の 腸内細菌をフィルターで除去した腸内細菌フリー粪 便を移植した患者群でも良好な結果が得られること が判明した ${ }^{34)}$ 。この結果からは腸内細菌が重要と考 えられてきたが実際には腸内細菌代謝産物が重要で ある可能性が示唆されている。そこで今後，腸内細 菌代謝産物が他のホストの腸内細菌に影響を与える のか，腸内細菌代謝産物が直接ホストの免疫防御に 働いているのか，詳細なメカニズムの検討が期待さ れる。

\section{おわりに}

腸内細菌叢と腸管免疫，炎症性腸疾患との関連性 について概説した，解析技術に進歩によって腸内細 菌と腸管免疫との関連性についての知見が蓄積され てきてはいるが, 解明されていない部分はなお多い. さらに，近年，腸管のみならず全身の免疫系や代謝 調節機構への影響が注目されてきている。腸内細菌
叢はプロバイオテイクスやFMT などよる直接の 治療介入対象となり得ると同時に，宿主であるヒ卜 との複雑な相互作用の中に，さまざまな疾患の病態 解明や新規治療の開発の助けとなる可能性を持って いる。 ヒトとの共生, 共存関係の中で, より重要な 役割を果たす菌種の同定や, 分子・遺伝子レベルで の相互作用の解明がなされることに期待したい.

文献

1) Ley, R.E., et al.: Ecological and evolutionary forces shaping microbial diversity in the human intestine. Cell. 124: 837-848, 2006.

2) Eckburg, P.B., et al.: Diversity of the human intestinal microbial flora. Science. 308: 1635-1638, 2005.

3) Frank, D.N., et al.: Molecular-phylogenetic characterization of microbial communityimbalances in human inflammatory bowel diseases. Proc Natl Acad Sci U S A. 104: 13780-13788, 2007.

4) Atarashi, K., et al.: Treg induction by a rationally selected mixture of Clostridiastrains from the human microbiota. Nature. 500: 232-236, 2013.

5) Okumura, R., et al.: Lypd8 promotes the segregation of flagellated microbiota and colonic epithelia. Nature. 532: 117-121, 2016.

6) Cash, H.L., et al.: Symbiotic bacteria direct expression of an intestinal bactericidal lectin. Science. 31: 1126-1130, 2006.

7) Levy, M., et al.: Microbiota-Modulated Metabolites Shape the Intestinal Microenvironment by Regulating NLRP6 Inflammasome Signaling. Cell. 163: 1428-1443, 2015.

8) Wlodarska, M., et al.: NLRP6 inflammasome orchestrates the colonic host-microbial interface by regulating goblet cellmucus secretion. Cell. 156: 1045-1059, 2014.

9) Wang, X., et al.: Follicular dendritic cells help establish follicle identity and promote $\mathrm{B}$ cell 
retention in germinal centers. J Exp Med. 208: 2497-2510, 2011.

10) Suzuki, K., et al.: The sensing of environmental stimuli by follicular dendritic cells promotes immunoglobulin A generation in the gut. Immunity. 33: 71-83, 2010.

11) Johnston, R.J., et al.: Bcl6 and Blimp-1 are reciprocal and antagonistic regulators of $\mathrm{T}$ follicular helper cell differentiation. Science. 325: 10061010, 2009.

12) Linterman, M.A., et al.: Follicular helper T cells are required for systemic autoimmunity. $J \operatorname{Exp}$ Med. 206: 561-576, 2009.

13) Atarashi, K., et al.: ATP drives lamina propria $\mathrm{T}(\mathrm{H}) 17$ cell differentiation. Nature. 455: 808-812, 2008.

14) Okai, S., et al.: High-affinity monoclonal IgA regulates gut microbiota and prevents colitis in mice. Nat Microbiol. 1: 16103, 2016.

15) Jostins, L., et al.: Host-microbe interactions have shaped the genetic architecture of inflammatory bowel disease. Nature. 491: 119-124, 2012.

16) Weaver, C.T., et al.: The Th17 pathway and inflammatory diseases of the intestines, lungs, and skin. Annu Rev Pathol. 8: 477-512, 2013.

17) Hirota, K., et al.: Plasticity of Th17 cells in Peyer's patches is responsible for the induction of $\mathrm{T}$ celldependent IgA responses. Nat Immunol. 14: 372379, 2013.

18) Ivanov, I.I., et al.: Induction of intestinal Th17 cells by segmented filamentous bacteria. Cell. 139: 485-498, 2009.

19) Atarashi, K., et al.: Th17 Cell Induction by Adhesion of Microbes to Intestinal Epithelial Cells. Cell. 163: 367-380, 2015.

20) Dreux, N., et al.: Point mutations in FimH adhesin of Crohn's disease-associated adherent-invasive Escherichia coli enhance intestinal inflammatory response. PLoS Pathog. 9: e1003141, 2013.

21) Viladomiu, M., et al.: IgA-coated E. coli enriched in Crohn's disease spondyloarthritis promote TH17-dependent inflammation. Sci Transl Med. 9. pii: eaaf9655, 2017.

22) Tan, T.G., et al.: Identifying species of symbiont bacteria from the human gut that, alone, can induce intestinal Th17 cells in mice. Proc Natl Acad Sci U $S$ A. 113: E8141-E8150, 2016.
23) Sokol, H., et al.: Faecalibacterium prausnitzii is an anti-inflammatory commensal bacterium identified by gut microbiota analysis of Crohn disease patients. Proc Natl Acad Sci U S A. 105: 1673116736, 2008.

24) Sokol, H., et al.: Low counts of Faecalibacterium prausnitzii in colitis microbiota. Inflamm Bowel Dis. 15: 1183-1189, 2009.

25) Furusawa, Y., et al.: Commensal microbe-derived butyrate induces the differentiation of colonic regulatory T cells. Nature. 504: 446-450, 2013.

26) Hayashi, A., et al.: A single strain of Clostridium butyricum induces intestinal IL-10-producing macrophages to suppress acute experimental colitis in mice. Cell Host Microbe. 13: 711-722, 2013.

27) Mennigen, R., et al.: Probiotic mixture VSL\#3 protects the epithelial barrier by maintaining tight junction protein expression and preventingapoptosis in a murine model of colitis. Am J Physiol Gastrointest Liver Physiol. 296: G1140-1149, 2009.

28) Van Nood, E., et al.: Duodenal infusion of donor feces for recurrent Clostridium difficile. $N$ Engl $J$ Med. 368: 407-415, 2013.

29) Mizuno, S., et al.: Single fecal microbiota transplantation failed to change intestinal microbiota and had limited effectiveness against ulcerative colitis in Japanese patients. Intest Res. 15: 68-74, 2017.

30) Moayyedi, P., et al.: Fecal Microbiota Transplantation Induces Remission in Patients With Active Ulcerative Colitis in a Randomized Controlled Trial. Gastroenterology. 149: 102-109.e6, 2015.

31) Rossen, N.G., et al.: Findings From a Randomized Controlled Trial of Fecal Transplantation for $\mathrm{Pa}-$ tients With Ulcerative Colitis. Gastroenterology. 149: 110-118.e4, 2015.

32) Paramsothy, S., et al.: Multidonor intensive faecal microbiota transplantation for active ulcerative colitis: a randomised placebo-controlled trial. Lancet. 389: 1218-1228, 2017.

33) Cui, B., et al.: Fecal microbiota transplantation through mid-gut for refractory Crohn's disease: safety, feasibility, and efficacy trial results. J Gastroenterol Hepatol. 30: 51-58, 2015.

34) Ott, S.J., et al.: Efficacy of Sterile Fecal Filtrate Transfer for Treating Patients With Clostridium difficile Infection. Gastroenterology. 152: 799811.e7, 2017. 